\title{
Bidding Strategies and Equity Auction Based on Social Network
}

\author{
LI Chengzhi ${ }^{1}$, Zhang Ping ${ }^{2}$
}

1. LI Chengzhi, Xiamen, Fujian, China, China Minsheng Bank Corporation Xiamen Branch,361004, Emai: 18164064020@126.com.

2. Zhang Ping, School of Economics \& Management, Wuhan University, Hubei, China, 430072 , Email: wudazhangping@126.com.

Keywords: bidding strategy; equity auction; social network

\begin{abstract}
Equity auction has advantages in revealing the real equity prices and allocating resources efficiently, and is an important way of venture capital exit. Outside investors can establish link relationship between each other and thus form a social network. This article establishes an equity affiliated value auction mechanism, uses Netlogo simulation to show the formation and evolution of social networks between outside investors, in the hope of giving a more general and reasonable characterization and describe of the equity affiliated value auction.
\end{abstract}

\section{Introduction}

It has been more and more important that venture capitalists turn enterprise equities into earnings in the best way at the appropriate time to realize the investment exit. The successful exit has the direct bearing on their capital efficiency and reinvestment; it also affects their reputation and investment confidence. Due to the existence of information asymmetry in the market of venture investment equity exit, outside investors are difficult to fully understand the real value of the equity of the venture enterprise, and therefore they are reluctant to provide their real values, so the venture capitalists can’t achieve the goal of maximizing their profits.

Douglas Cumming \& Sofia Johan (2008) introduce a new dataset comprising all venture capital exits in Canada for the years 1991 to 2004. The data provides strong support for the conjecture that the ability to mitigate information asymmetries and agency costs is a central factor in influencing exit outcomes. Zheng Junjun, Zhong Hongbo (2012) designed an auction mechanism with the integrated use of auction and mechanism design theory. The mechanism met the individual rationality and incentive compatibility, and also obtained the optimal equity auction mechanism. In order to portray the changing process of the investors' equity assessment more accurately, we introduce the related theories of social networks. In recent years the knowledge of the social network has been widely used in many fields such as opinion dynamics, through the links individuals can realize information exchange and interaction in the network, so social network knowledge is also helpful to the study of the investors' assessments changing processes in equity auction.

Considered from the perspective of venture capitalists in this paper, we suppose that the outside investors can make information interaction through social links, and establish the venture capital exit equity auction model with the theory of affiliated value auction, at last, we simulate the model with Netlogo and analyze outside investors' bidding strategies and venture capitalists' profit with the existence of social networks.

\section{Investors’ Bidding Strategies and Equity Auction}

The equity auction is composed of a seller and $n$ buyers, venture capitalist and outside investors is risk neutral; their purposes are to maximize their own benefits. We assume there is no transaction cost, and outside investors have no budget constraint, the winner only needs to pay the bid price.

In this paper, we refer the famous scale-free network put forward by Barabasi and Albert in 
1999. Assuming the outside investors go into the network with time sequence, so the investor 0 has been existed in the network at $t=0$ and the investor 1 will establish a link with investor 0 by probability 1 at $\mathrm{t}=1$ The investors entered earlier can collect more information, so the new investors are more inclined to establish links with them, note the link-numbers of investor $\mathrm{i}$ at time $\mathrm{t}$ is $d_{i}(t)$ and the total link-numbers of the network $\sum_{j=0}^{t-1} d_{j}(t-1)$, so the probability of a new investor establishes a link with i can be expressed as $p(i-l i n k)=\frac{d_{i}(t-1)}{\sum_{j=0}^{t-1} d_{j}(t-1)} / \sum_{j=0}^{t-1} d_{j}(t-1),(t>1)$. The distribution of outside investors' valuation for equity is normal distribution $N(30,3)$, the initial bidding price of investor $\mathrm{i}$ is $b_{i}(0)=\left(1-s_{i}\right) x_{i}, s_{i} \in[0,1]$, the initial assessment is $\theta_{i}(0) \sim U(0.5,1)$. the investors will constantly search for the information of others in order to modify and change their own assessments and bidding prices, the update process is: $b_{i}(t+1)=b_{i}(t) \theta_{i}(t+1) / \theta_{i}(t)$.

Outside investors i and j can exchange their own information of assessments through their link, we can get the influence weight of investor $\mathrm{i}$ to $\mathrm{j}: a_{i j}(t)=d_{j}(t) / \sum_{j=1}^{k} d_{j}(t)$, and $a_{i 1}(t)+a_{i 2}(t)+\cdots+a_{i n}(t)=1$. Considering investor $\mathrm{i}$ attaches a fixed weight $g_{i}$ to his initial assessment, thus we can get his assessments at time $\mathrm{t}+1$ as $\theta_{i}(t+1)=g_{i} \theta_{i}(0)+\left(1-g_{i}\right)\left[a_{i 1}(t) \theta_{1}(t)+a_{i 2}(t) \theta_{2}(t)+\cdots+a_{i n}(t) \theta_{n}(t)\right]$.

In order to avoid "the winner's curse" and increase expected earnings, outside investors want to obtain equity with a price lower than their valuation. It conflicts with the venture capitalist' goal which aims at revealing their true value. Therefore, as a mechanism designer, venture capitalist need incentives to encourage outside investors "tell the truth", we put forward a hypothesis about the venture capitalists' incentives: In order to encourage outside investor i bid his true valuation xi, venture capitalist decide to give the winner q times of his bidding to reward, and the reservation price is zero. $\forall j \in\{1, \cdots, i-1, i+1, \cdots, n\}$, we can get the expected income of venture capitalist: $U(t)=\left(b_{i}(t)-q b_{i}(t)\right) p\left\{b_{i}(t) \geq b_{j}(t)\right\} \quad$, for $\mathrm{i}$, the incentive compatibility restraint is $q x_{i} p\left\{x_{i} \geq x_{j}\right\} \geq\left(x_{i}-b_{i}(t)+q b_{i}(t)\right) p\left\{b_{i}(t) \geq b_{j}(t)\right\}$, it means that a outside investor's income gained by bidding the real valuation is not less than the income gained by the "lie"; the individual rationality restraint is $x_{i}-b_{i}(t)+q b_{i}(t) \geq 0$ and means that outside investors' minimum earnings is not less than zero. With the above-mentioned analysis, we can construct the auction model on the basis of social network:

$$
\begin{aligned}
& \max U(t)=\left(b_{i}(t)-q b_{i}(t)\right) p\left\{b_{i}(t) \geq b_{j}(t)\right\}, \forall j \in\{1, \cdots, i-1, i+1, \cdots, n\} \\
& b_{i}(t+1)=b_{i}(t) \frac{g_{i} \theta_{i}(0)+\left(1-g_{i}\right)\left[a_{i 1}(t) \theta_{1}(t)+a_{i 2}(t) \theta_{2}(t)+\cdots+a_{i n}(t) \theta_{n}(t)\right]}{\theta_{i}(t)} \\
& q x_{i} p\left\{x_{i} \geq x_{j}\right\} \geq\left(x_{i}-b_{i}(t)+q b_{i}(t)\right) p\left\{b_{i}(t) \geq b_{j}(t)\right\} \\
& x_{i}-b_{i}(t)+q b_{i}(t) \geq 0 \\
& 0 \leq p\left\{b_{i}(t) \geq 0\right\} \leq 1,0 \leq g_{i} \leq 1,0 \leq a_{i j} \leq 1
\end{aligned}
$$

\section{Simulation and analysis}

From figure 1, we can see that the highest bidding price and seller's earning stabilize at 33, which is very close to the mean value 30, and venture capitalist achieves the goal to incentive external investors bid their true valuations at a very low cost in the presence of social network, it shows the effectiveness of our mechanism. 


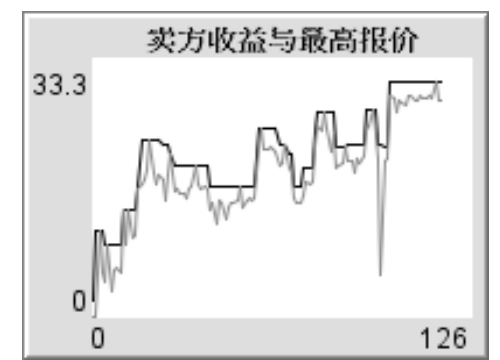

Figure 1. The highest bidding price and seller's earning

\section{Conclusion}

Overall, when a network exists between outside investors to exchange information and make interactions in the equity auction, they have more equity assessment information for reference. Venture capitalist's incentive strength q which needs to be pay to the investors continuously reduced and stabilize in a relatively low level, it proves the effectiveness of the auction mechanism

\section{References}

[1] Zsoylev H N, Walden J. Asset pricing in large information networks[J]. Journal of Economic Theory, 2011, 146(6): 2252-2280.

[2] De Groot M H. Reaching a consensus[J]. Journal of the American Statistical Association, 1974, 69(345): 118-121.

[3] Barabási A L, Albert R. Emergence of scaling in random networks[J]. Science, 1999, 286(5439): 509-512.

[4] Gompers P A. Grandstanding in the venture capital industry[J]. Journal of Financial economics, 1996, 42(1): 133-156.

[5] Hegselmann R, Krause U. Opinion dynamics and bounded confidence models, analysis, and simulation[J]. Journal of Artificial Societies and Social Simulation, 2002, 5(3): 1-24.

[6] Bala V, Goyal S. Learning from neighbours[J]. The Review of Economic Studies, 1998, 65(3): 595-621. 